\title{
Effect of variables on the thickness of an edible coating applied on frozen fish - Establishment of the concept of safe dipping time
}

\author{
Nuno M. Soares, Tiago A. Fernandes, António A. Vicente \\ Centre for Biological Engineering, Universidade do Minho, Campus de Gualtar, 4710-057, Braga, Portugal
}

\section{A R T I C L E I N F O}

\section{Article history:}

Received 19 May 2015

Received in revised form

8 October 2015

Accepted 10 October 2015

Available online 21 October 2015

\section{Keywords:}

Frozen salmon

Glazing thickness

Chitosan thickness

Safe dipping time

\begin{abstract}
A B S T R A C T
Glazing is a technique used to retard fish deterioration during storage. This work focuses on the study of distinct variables (fish temperature, coating temperature, dipping time) that affect the thickness of edible coatings (water glazing and $1.5 \%$ chitosan) applied on frozen fish. Samples of frozen Atlantic salmon (Salmo salar) at $-15,-20$, and $-25^{\circ} \mathrm{C}$ were either glazed with water at $0.5,1.5$ or $2.5{ }^{\circ} \mathrm{C}$ or coated with $1.5 \%$ chitosan solution at $2.5,5$ or $8^{\circ} \mathrm{C}$, by dipping during $10-60 \mathrm{~s}$. For both water and chitosan coatings, lowering the salmon and coating solution temperatures resulted in an increase of coating thickness. At the same conditions, higher thickness values were obtained when using chitosan (max. thickness of $1.41 \pm 0.05 \mathrm{~mm}$ ) compared to water (max. thickness of $0.84 \pm 0.03 \mathrm{~mm}$ ). Freezing temperature and crystallization heat were found to be lower for $1.5 \%$ chitosan solution than for water, thus favoring phase change. Salmon temperature profiles allowed determining, for different dipping conditions, whether the salmon temperature was within food safety standards to prevent the growth of pathogenic microorganisms. The concept of safe dipping time is proposed to define how long a frozen product can be dipped into a solution without the temperature raising to a point where it can constitute a hazard.
\end{abstract}

(C) 2015 Elsevier Ltd. All rights reserved.

\section{Introduction}

Seafood is unanimously a great source of important nutritional components for a healthy diet (Rodriguez-Turienzo et al., 2011). As stated by James (2013), the benefits of seafood consumption far outweigh its possible risks. Fish consumption provides energy, protein and important nutrients like long-chain $\omega-3$ polyunsaturated fatty acids, and has positive impacts in the health of consumers. Fish deterioration is most commonly a result of microbial growth, oxidation and enzymatic autolysis and can be prevented using methods like freezing, salting, smoking, fermentation, drying and canning. About $30 \%$ of landed fish is lost because of microbial activity. The increase of world's population and the need to store and transport fish are factors that enhance the importance of this issue and make fish preservation imperative in order to maintain its nutritional properties, flavor, color, texture and extend its shelf life (Ghaly et al., 2010).

Freezing is a widely used technique in fish preservation due to its ability to inhibit enzyme activity and to retard the growth of

\footnotetext{
* Corresponding author.

E-mail address: avicente@deb.uminho.pt (A.A. Vicente).
}

microorganisms. This method requires removal of heat from the fish body in order to lower its temperature, generally to $-18{ }^{\circ} \mathrm{C}$ or below (Ghaly et al., 2010).

Traditional frozen storage of fish may lead to a progressive loss of intrinsic and sensory characteristics (Vanhaecke et al., 2010). Glazing is a widely used technique to protect fish from this loss, and can be defined as the application of a layer of ice on frozen products' surface by spraying or brushing water or by dipping in a water bath (Žoldoš et al., 2011). During frozen or cold storage, marine products may suffer dehydration and surface drying resulting from the contact with very cold temperatures and temperature fluctuations (freezer burn). Seafood glazing acts as a barrier preventing oxidation or rancidity, since the ice layer reduces the exposure to oxygen and prevents the contact between the product's surface and the air (Johnston et al., 1994; Vanhaecke et al., 2010). A good glazing is essential in order to minimize quality loss resulting from exposure to factors like rate of freezing and thawing, temperature fluctuations, high storage temperature, incorrect transportation, distribution and consumption temperatures. However, a poor glazing may jeopardize fish quality because of partial thawing of the fish and slow refreezing in cold storage (Žoldoš et al., 2011). Therefore the glazing process must be closely controlled, to form a uniform glaze on the fish surface. The factors that influence the amount of 
glaze applied are glazing time, water temperature, fish temperature and size and shape of the product (Johnston et al., 1994). Given the properties of the chitosan solution (an aqueous solution) these same factors are expected to directly influence the coating thickness.

The determination of the amount of glaze applied can be very important for the evaluation of its protective function and for economic reasons. A low glaze application $(<6 \%)$ may not ensure fish protection and can lead to a decrease of quality in the final product. From an economic perspective, an excessive glazing (over $12 \%$ ) may assure higher profits to sellers, since this will increase the weight and consequently the price consumers pay for the fish product. In both cases, the consumer is the most affected part (Vanhaecke et al., 2010).

A great attention has been given to edible food packaging as it becomes an integral part of the food that could be eaten (Baldwin, 2007). The motivation for the increase of interest and research activity in edible packaging is due to the increasing consumer demand for safe, convenient, stable foods and also the awareness of the negative environmental impacts of non-biodegradable waste resulting from packaging (De Azeredo, 2012) (Debeaufort et al., 1998).

Chitin is the second most abundant naturally occurring biopolymer, after cellulose, and is found in the exoskeleton of crustaceans, in fungal cell walls and in other biological materials. Chitosan is the $\mathrm{N}$-deacetylated derivative of chitin, being its structure composed of 2 -amino-2-deoxy- $\beta$-D-glucose (GlcN) in a $\beta(1,4)$ linkage and occasional $\mathrm{N}$-acetyl glucosamine (GlcNAc) residues (Srinivasa and Tharanathan, 2007). Chitosan is a biomolecule with great potential because of its numerous physical-chemical and biomedical characteristics, e.g. antimicrobial activity, biodegradable, nontoxic, antifungal, biocompatible and nonantigenic. Chitosan, its oligomers and many derivatives emerged as new biomaterials for a large range of industries as food and agriculture, medical, cosmetics, pharmaceutical and textile. In particular, it has been used extensively as a food coating material. Recently, the European Food Safety Authority (EFSA) panel confirmed that a cause-effect relationship has been established between the consumption, by adults, of $3 \mathrm{~g}$ of chitosan daily and the normal blood LDL-cholesterol concentrations (EFSA, 2011).

The objective of this work is to better understand the variables that affect the coating thickness in frozen salmon (dipping time, salmon temperature and coating temperature) comparing to the traditional water glazing.

\section{Materials and methods}

\subsection{Fish preparation}

Frozen fillets of Atlantic salmon (Salmo salar) provided by Vanibru - Comércio de Produtos Alimentares (Braga, Portugal) with proximally $1 \mathrm{~kg}$ were carefully and evenly cut in a parallelepipedic shape with a vertical bone sawing machine (FK 32, BIZERBA, Germany) in a refrigerated room, where the temperature did not exceed $8{ }^{\circ} \mathrm{C}$. The dimensions of the salmon pieces were approximately $6 \mathrm{~cm} \times 2 \mathrm{~cm} \times 2.5 \mathrm{~cm}$ and presented an average weight of $26.4 \pm 3.4 \mathrm{~g}$ for chitosan coating tests and $29.42 \pm 2.01 \mathrm{~g}$ for water glazing tests. These samples were stored in a freezer with pre-established and fixed temperatures of $-15,-20$ or $-25^{\circ} \mathrm{C}$, and were stabilized at least $24 \mathrm{~h}$ in those conditions prior to use.

\subsection{Chitosan coating solution preparation}

The chitosan solution was prepared at $1.5 \% \mathrm{w} / \mathrm{v}$. In a 2 -L flask $22.2 \mathrm{~mL}$ of $1 \% \mathrm{v} / \mathrm{v}$ lactic acid (90\% ( $\mathrm{w} / \mathrm{w})$ purity) were added and the volume was made up with distilled water (Soares et al., 2015). Then the flask was placed in a heating plate at $45{ }^{\circ} \mathrm{C}$ under agitation. Slowly, $30 \pm 0.1 \mathrm{~g}$ of chitosan (from Golden-shell Biochemical Co. Ltd. China, with a 91\% deacetylation degree) were added and stirred. This solution was left overnight under stirring to complete dissolution. After cooling, the chitosan solution was transferred to a closed glass container and stored in the refrigerator at $2.5,5$ or $8{ }^{\circ} \mathrm{C}$.

In the case of glazing with water no preparation was required. The dips were performed in a glazing bath equipment (HRG, GL3001, Spain) at $0.5,1.5$ or $2.5^{\circ} \mathrm{C}$.

\subsection{Edible coating for salmon}

Samples of frozen salmon were weighed (RADWAG WLC 6/A2/C/ 2, Poland) and subsequently immersed in the chitosan solution/ water for $10,20,30,40,50$ or $60 \mathrm{~s}$ and left to drain for about $180 \mathrm{~s}$. Then salmon was reweighed and the amount of glazing was calculated using Equation (1), where $W_{i}$ is the weight of salmon before and $W_{f}$ is the weight of salmon after application of the coating. All procedures were performed in triplicate. After coating application the salmon samples were packed in numerated zip-lock polyethylene bags and stored at $-25{ }^{\circ} \mathrm{C}$ for at least $24 \mathrm{~h}$.

$\%$ Glazing $=\frac{W_{f}-W_{i}}{W_{f}} \cdot 100$

Table 1 displays the various combinations of temperatures of salmon and temperatures of coatings/water tested. The solution temperature was monitored by an infrared Pronto Plus thermometer (HANNA Instruments, HI99556-10, Romania) with the respective probe (HANNA Instruments, HI765PW, Romania). The salmon temperature was monitored by a data logger (DS7922 1Wire ${ }^{\mathbb{R}}$ Thermochrom ${ }^{\circledR}$ iButton ${ }^{\circledR}$, Dallas Semiconductor Inc., U.S.A.) stored in the industrial freezer together with salmon samples.

\subsection{Images of salmon samples}

The salmon pieces described in 2.1 were cut into thinner slices with only a few millimeters wide using the same cutting conditions (temperature and equipment). These samples were placed in numbered zip-lock polyethylene bags and stored in the freezer at $-25{ }^{\circ} \mathrm{C}$ to stabilize the temperature. Subsequently the samples were quickly transported to the laboratory and placed in a ultrafreezer (Cryocell DD86-750P) at $-80{ }^{\circ} \mathrm{C}$ for at least $24 \mathrm{~h}$.

Each salmon sample was placed in the center of an OLYMPUS magnifying glass plate (OLYMPUS SZ-CTV, Japan) and photographed with the 0.67 magnification using the program "Image-Pro Plus" (op + I). This allowed measuring the coating thickness using the appropriate calibration of the optical system. The coating thickness was measured at various points (Fig. 1) and the process was repeated for the remaining samples.

\subsection{Samples analysis}

\subsubsection{Differential scanning calorimetry (DSC)}

DSC measurements were performed with a PYRIS Diamond DSC (Perkin Elmer, USA). About $30 \mathrm{mg}$ of $1.5 \% \mathrm{w} / \mathrm{v}$ chitosan solution was placed in aluminum DSC pans. The samples were heated from -30 to $50{ }^{\circ} \mathrm{C}$ at a heating rate of $10{ }^{\circ} \mathrm{C} \min ^{-1}$ under a nitrogen atmosphere.

\subsubsection{Determination of temperature profile}

The temperature profile of salmon was determined using Equation (2) (Crank, 1979), which represents the variation of the salmon final temperature from the center to the surface. 
Table 1

Coating/water and salmon temperatures of the tests carried out in the present work.

\begin{tabular}{llr}
\hline & Coating temperatures $\left({ }^{\circ} \mathrm{C}\right)$ & Salmon temperature $\left({ }^{\circ} \mathrm{C}\right)$ \\
\hline Chitosan & $(2.4 \pm 0.11) ;(4.84 \pm 0.27) ;(7.75 \pm 0.49)$ & $(-11.90 \pm 0.33)$ \\
Water & $(0.51 \pm 0.06) ;(1.58 \pm 0.09) ;(2.53 \pm 0.07)$ & $(-17.64 \pm 0.70)$ \\
& & $(-22.42 \pm 0.76)$ \\
\hline
\end{tabular}
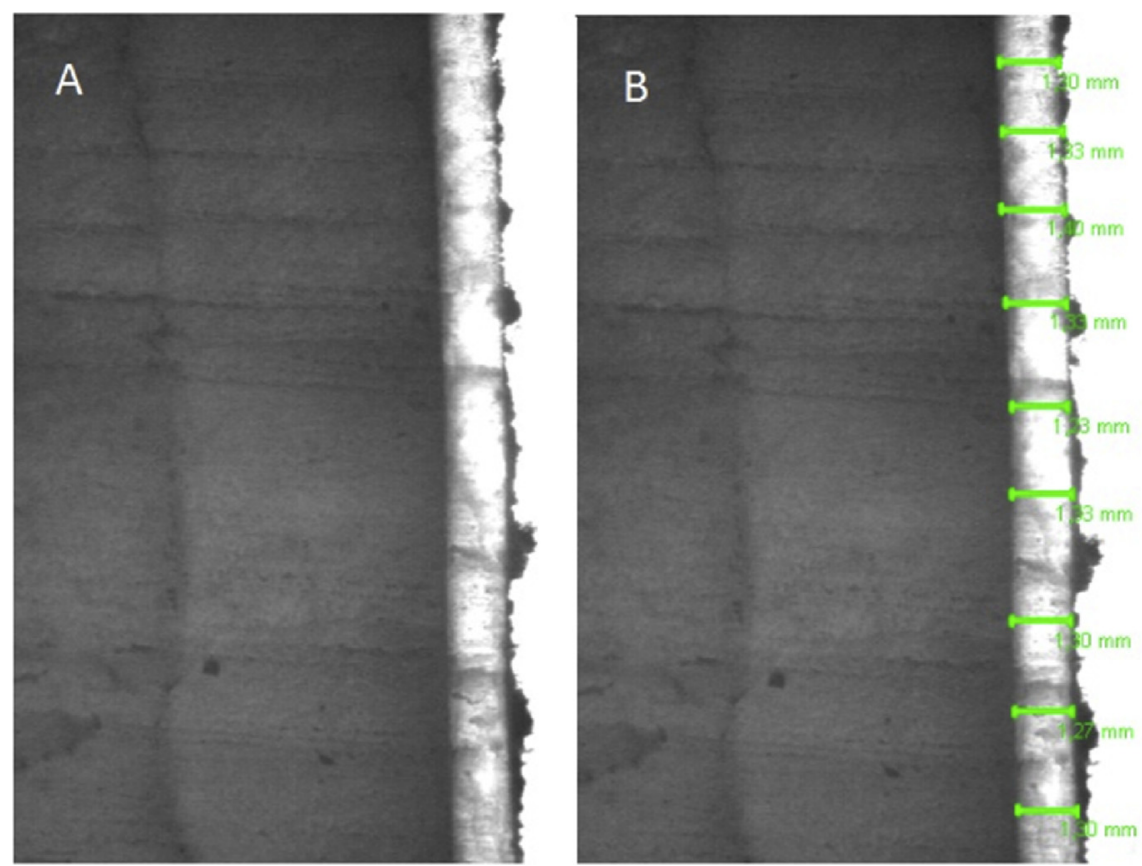

Fig. 1. Photograph taken to salmon wall after coating with chitosan (A) and corresponding measurements (B)

$$
\begin{aligned}
\frac{T-T_{W}}{T_{0}-T_{W}}= & \frac{4}{\pi} \sum_{\mathrm{n}=0}^{\infty} \frac{(-1)^{\mathrm{n}}}{2 \mathrm{n}+1} \cos \left(\frac{(2 \mathrm{n}+1) \pi \cdot x}{2 L}\right) \exp \\
& \times\left(-\frac{\alpha \cdot(2 \mathrm{n}+1)^{2} \pi^{2} t}{4 L^{2}}\right)
\end{aligned}
$$

Where: $T(\mathrm{~K})=$ temperature at the coordinate $x, T_{\mathrm{w}}(\mathrm{K})=$ surface temperature, $T_{0}(\mathrm{~K})=$ initial temperature, $x(\mathrm{~m})=$ depth, $L$ $(\mathrm{m})=$ half-thickness and $\alpha\left(\mathrm{m}^{2} \mathrm{~s}^{-1}\right)=$ thermal diffusivity.

From this profile, it was possible to calculate the average temperature $\left(T_{a v}\right)$ of salmon for each dipping time, by calculating the integral of the curve corresponding to the representation of $T$ versus $x$. This representation was made using a 2 nd order polynomial fit, which allowed calculating the average temperature using Equation (3):

$T_{a v}=\frac{\int_{x_{1}}^{x_{2}} T d x}{\Delta x}$

\subsubsection{Determination of heat transferred}

The heat received by salmon samples upon immersion in the coating was calculated using Equation 4:

$Q_{\text {salmon }}=m_{\text {salmon }} C_{p \text { salmon }}\left(T_{a v}-T_{i}\right)$

Where: $Q_{\text {salmon }}(\mathrm{J})=$ heat transferred to salmon, $m_{\text {salmon }}$ $(\mathrm{kg})=$ initial salmon mass, $C_{p \text { salmon }}\left(\mathrm{J} \mathrm{kg}^{-1} \mathrm{~K}^{-1}\right)=$ heat capacity of salmon, $T_{a v}(\mathrm{~K})=$ salmon average temperature, $T_{i}(\mathrm{~K})=$ salmon initial temperature.

\subsubsection{Statistical analyses}

The tests conducted for each set of parameters were performed in triplicate. For each triplicate five measurements of thickness were made, which resulted in 15 thickness values for each condition. The data were subjected to one-way analysis of variance (ANOVA) using STATISTICA 10 software (StaSoft Inc. 2013), while average values were compared by Tukey's test with the level of significance set at $p<0.05$.

\section{Results and discussion}

\subsection{Differential scanning calorimetry (DSC)}

Differential scanning calorimetry was used to determine the freezing point of the chitosan solution and its crystallization heat. The results of heat flow regarding a $1.5 \% \mathrm{w} / \mathrm{v}$ chitosan solution showed the following properties: at a freezing temperature of $-0.51{ }^{\circ} \mathrm{C}$ chitosan presented an enthalpy change of $250.23 \mathrm{~J} \mathrm{~g}^{-1}$, while for water an enthalpy change of $334 \mathrm{~J} \mathrm{~g}^{-1}$ at the freezing temperature of $0{ }^{\circ} \mathrm{C}$ was determined (both measured under atmospheric pressure).

\subsection{Thickness of coatings from chitosan solutions}

The application of chitosan solutions at $2.5,5$ and $8{ }^{\circ} \mathrm{C}$ on frozen 
fish at $-25,-20$ and $-15^{\circ} \mathrm{C}$ with different dipping times $(10,20,30$, $40,50,60 \mathrm{~s})$ resulted in different coating thicknesses. The final thickness for each set of parameters was measured through the pictures taken to the corresponding salmon samples. The variation of coating thickness with dipping time is represented in Fig. 2.

These results show that for salmon at $-25{ }^{\circ} \mathrm{C}$, thickness increases with higher dipping time and lower coating temperature. For short dipping times (10-30 s), the thickness for the temperatures of 8 and $5{ }^{\circ} \mathrm{C}$ are similar and did not compensate the energy spent to lower the chitosan solution temperature. However in the case of $2.5^{\circ} \mathrm{C}$, the opposite is verified and the thickness for these conditions is consistently higher. This can be explained by the lower temperature of the coating solution $\left(2.5^{\circ} \mathrm{C}\right)$, which is closer to chitosan's freezing point, thus requiring a lower quantity of energy for the phase change (liquid to solid). As chitosan solution temperature drops, specific heat also decreases (less heat is required to lower the temperature) which makes the temperature of $2.5{ }^{\circ} \mathrm{C}$ more effective from a heat exchange point of view (Fellows, 2000). For longer dipping times (60 s), the coating thickness values obtained for 2.5 and $5{ }^{\circ} \mathrm{C}$ are statistically similar, reaching a maximum of $1.41 \pm 0.05 \mathrm{~mm}$, while at a temperature of
$8{ }^{\circ} \mathrm{C}$, lower thickness values were attained $(1.24 \pm 0.03 \mathrm{~mm})$.

Using the same conditions of chitosan solution temperatures and dipping time, an increase of the salmon temperature in general decreases the final thickness of the coating. This can be explained based on the fact that the difference between the temperature of the salmon and that of the coating is smaller, therefore there is a lower amount of energy (in the form of heat) being transferred from the coating to the salmon. However, for longer dipping times the differences between the thickness values obtained for the three chitosan temperatures are progressively reduced, since at $60 \mathrm{~s}$ there is no statistically significant difference between all thickness results. In these conditions (salmon temperature of $-20^{\circ} \mathrm{C}$ ), for the longest dipping time (60 s) the maximum value of thickness obtained was $1.08 \pm 0.03 \mathrm{~mm}$, a significantly lower result comparing with the salmon at $-25^{\circ} \mathrm{C}$ that was $1.41 \pm 0.05 \mathrm{~mm}$.

The results for salmon at $-15{ }^{\circ} \mathrm{C}$ confirm the expected trend. A dipping time of $10 \mathrm{~s}$ together with a coating temperature of $8{ }^{\circ} \mathrm{C}$ yielded the smallest thickness of all chitosan coatings $(0.36 \pm 0.03 \mathrm{~mm})$, being considerably smaller than the $0.55 \pm 0.02 \mathrm{~mm}$ and $0.63 \pm 0.03 \mathrm{~mm}$ achieved for coating temperatures of $5{ }^{\circ} \mathrm{C}$ and $2.5^{\circ} \mathrm{C}$, respectively. For longer dipping times
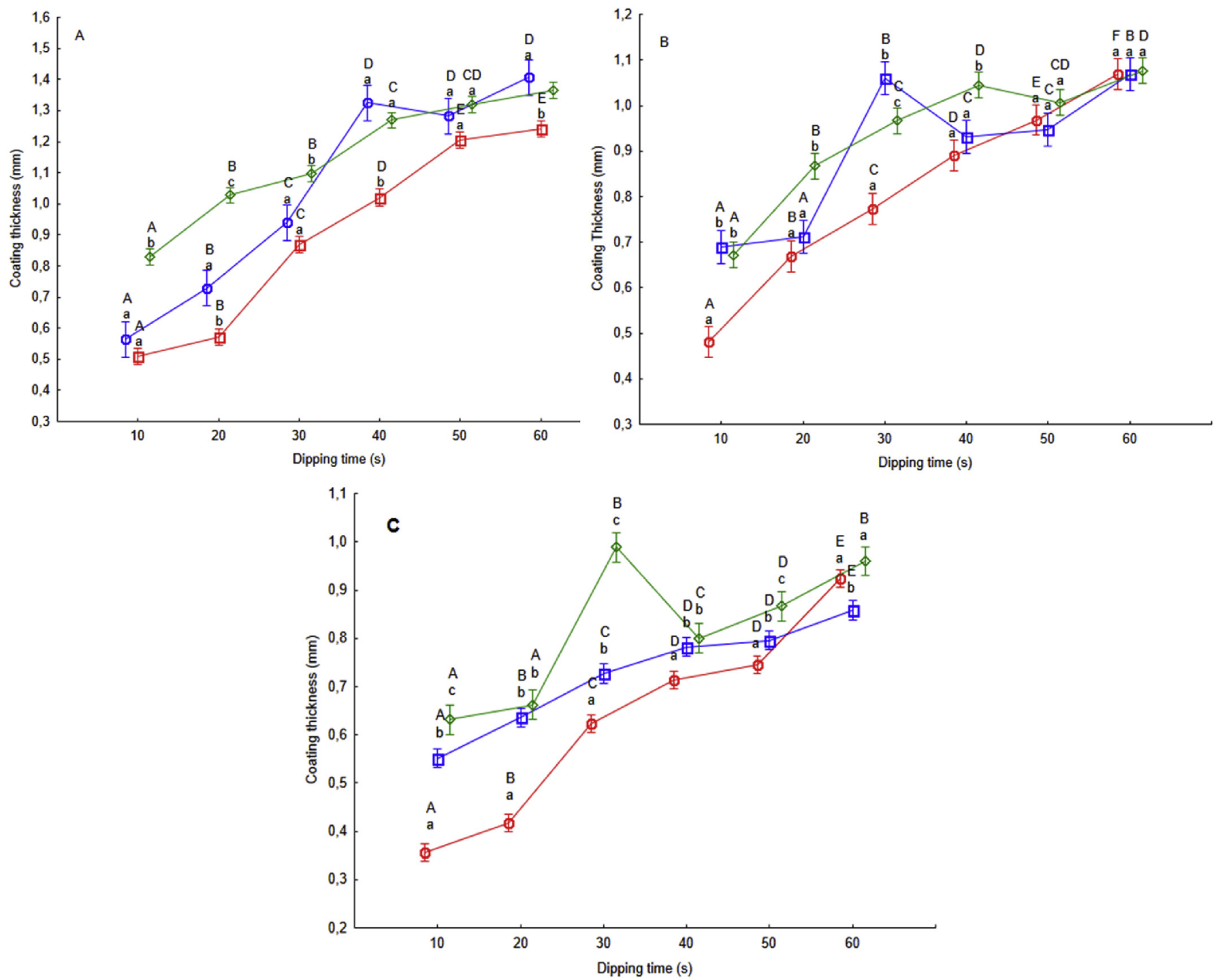

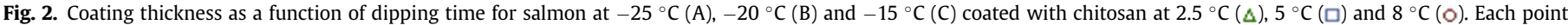

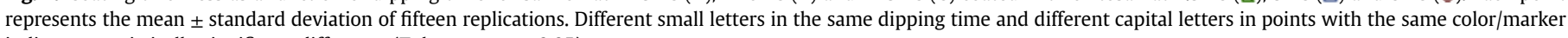
indicate a statistically significant difference (Tukey test, $p<0.05$ ). 
(40-60 s) the difference between coatings thickness values is reduced.

A study performed by El-Hefian et al. (2010) showed that as chitosan solution temperature rises, the correspondent viscosity falls. A higher viscosity can assure a superior adhesion between salmon and chitosan solution leading to a higher final thickness, since it has a greater resistance to movement. The thicknesses obtained for the various chitosan solution temperatures are in agreement with these results, since even though the temperature differences are relatively small, the chitosan solution temperature which presents higher thicknesses is the lowest $\left(2.5^{\circ} \mathrm{C}\right)$.

\subsection{Thickness of water glazing}

The application of water at $0.5,1.5$ and $2.5{ }^{\circ} \mathrm{C}$ on frozen fish at $-25,-20$ and $-15^{\circ} \mathrm{C}$ with different dipping times $(10,20,30,40$, $50,60 \mathrm{~s}$ ) results in different glazing thicknesses. The final thickness for each set of parameters was determined by measuring the images taken to the glazed salmon samples. The variation of glazing thickness with dipping time is represented in Fig. 3.

For salmon at $-25^{\circ} \mathrm{C}$, the temperature of water of $0.5^{\circ} \mathrm{C}$ shows the best overall results for short dipping times. However, for longer times, the difference tends to diminish and for $60 \mathrm{~s}$ of dipping time the glazing thickness values obtained at the three different temperatures are statistically similar, reaching a maximum of $0.84 \pm 0.03 \mathrm{~mm}$. It is also to be noted that in any case a stabilization or decrease of thickness was observed, therefore $60 \mathrm{~s}$ is not the limiting time for the increase of thickness. All the thickness values obtained with water glazing are lower than those obtained with chitosan coatings.

With the increase of the salmon temperature to $-20{ }^{\circ} \mathrm{C}$ the thicknesses of the glazing obtained for various water temperatures decreased. As previously observed with chitosan solutions' coatings, the cases in which this effect is most clear are those of higher water temperatures ( 1.5 and $2.5{ }^{\circ} \mathrm{C}$ ). The glazings obtained with water at these two temperatures have very similar thicknesses for all dipping times, with no statistically significant differences between the results. At the temperature of $0.5^{\circ} \mathrm{C}$, despite being the least affected by the increase of salmon temperature, it is also observable a decrease in the final thickness of the glazing, and its maximum value is $0.75 \pm 0.03 \mathrm{~mm}$. At water temperature of $2.5^{\circ} \mathrm{C}$ the glazing thickness stabilizes after $40 \mathrm{~s}$ while at 1.5 and $0.5^{\circ} \mathrm{C}$ a $60 \mathrm{~s}$ dipping time does not limit the thickness growth.

Using the same conditions of glazing water temperatures and dipping times, the increase of the salmon temperature consistently decreases the final glazing thickness, as expected. When salmon was at $-15^{\circ} \mathrm{C}$, the maximum thickness value $(0.61 \pm 0.02 \mathrm{~mm})$ was achieved for water glazing at $0.5^{\circ} \mathrm{C}$. It was possible to observe that after $40 \mathrm{~s}$, the thickness of glazing at 0.5 and $1.5{ }^{\circ} \mathrm{C}$ appeared to stabilize, with no significant differences after this dipping time. At the higher temperature of $2.5^{\circ} \mathrm{C}$, the thickness increased up to $40 \mathrm{~s}$ of dipping time, decreasing steeply for higher dipping times. Finally, the coating temperature of $2.5{ }^{\circ} \mathrm{C}$ may be considered as limiting to salmon temperatures higher than $-25{ }^{\circ} \mathrm{C}$ because glazing thickness stabilizes after only 30-40 s. Also, since the use of conditions that do not allow an increase in thickness and may effectively lead to an excessive increase in the salmon temperature is not at all advisable, the temperature of $-15^{\circ} \mathrm{C}$ for salmon can be limiting because after $40 \mathrm{~s}$ the thickness is maintained or even lowers.

The thickness values resulting from the application of chitosan and water at the same temperature $\left(2.5^{\circ} \mathrm{C}\right)$ in the same frozen salmon conditions show that for all tested temperatures of salmon the thickness achieved by application of chitosan solution is always significantly higher than that obtained by water glazing. The main reason is the lower heat of crystallization (as mentioned in 3.1). As this energy is lower for chitosan solution than for water, a larger amount of chitosan solution changes phase and adheres to the salmon. At a salmon temperature of $-25{ }^{\circ} \mathrm{C}$, the maximum thickness reached by the water glazing at $60 \mathrm{~s}$ is still lower than the minimum thickness achieved by chitosan coating at $10 \mathrm{~s}$. The same is true for salmon temperatures of -20 and $-15{ }^{\circ} \mathrm{C}$, being the maximum thickness of the water glazing always lower than the minimum thickness of the chitosan coating. It can be clearly concluded that chitosan solutions have a greater ability to change phase and adhere to the frozen salmon.

A final analysis was carried out to compare the best results presented by water glazing (salmon temperature of $-25{ }^{\circ} \mathrm{C}$ and water temperature of $0.5^{\circ} \mathrm{C}$ ) with the worst result presented by chitosan coating (salmon temperature of $-15{ }^{\circ} \mathrm{C}$ and chitosan temperature of $8{ }^{\circ} \mathrm{C}$ ). These results show that despite until $30 \mathrm{~s}$ of dipping the water presents higher thicknesses, from that dipping time onwards both thicknesses are similar, with chitosan showing a better result for dipping times of $60 \mathrm{~s}$. The highest operational costs in the frozen fish processing industry come from the use of electrical power required to maintain very low temperatures in glazing baths, cold chambers and equipments used to lower the products' temperature before entering in the production line (e.g. cooling tunnels). It can thus be inferred that by replacing common water glazing (where salmon can be kept at $-25^{\circ} \mathrm{C}$ or below that, and the glazing water bath is usually at $0.5^{\circ} \mathrm{C}$ ) by the application of the chitosan coating solution (at $8{ }^{\circ} \mathrm{C}$, which is a common room temperature in this type of industry, with the salmon at $-15^{\circ} \mathrm{C}-$ regular freezers can be used for this temperature - as tested in the
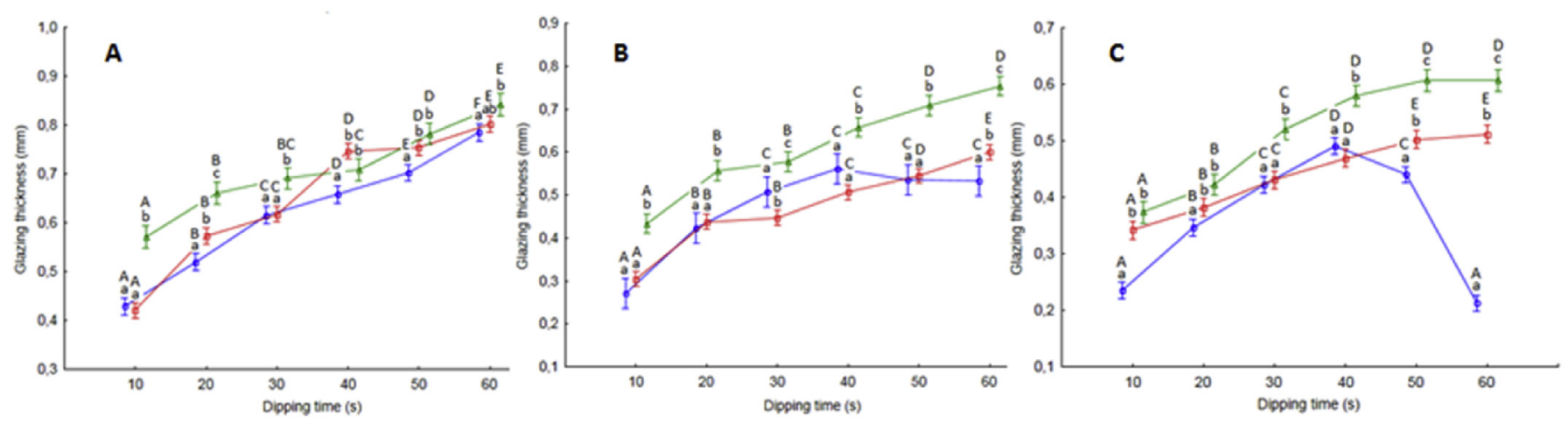

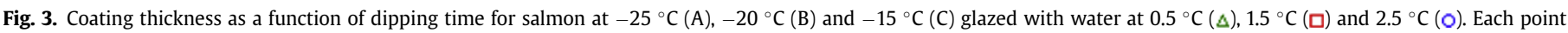

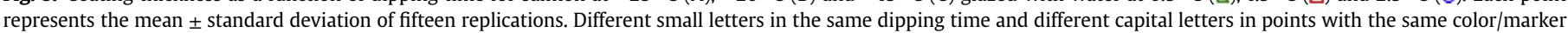
indicate a statistically significant difference (Tukey test, $p<0.05$ ). 
present work), significant energy savings are to be expected. However, when considering an overall strategy, any energetic aspect should be considered along with quality features (e.g. lipid oxidation) and their dependence on storage temperature.

\subsection{Temperature profiles and the concept of safe dipping time (SDT)}

The temperature of $-5{ }^{\circ} \mathrm{C}$ is the minimum temperature necessary for growth of pathogenic bacteria associated with fish (FDA, 2011; Huss et al., 2004; Jay, 2012). In this context, the availability of temperature profiles for frozen salmon is very important in order to determine the salmon temperature at any point for different dipping times and to check if during the glazing/coating process salmon does not exceed the critical temperature of $-5^{\circ} \mathrm{C}$ in most of its points. Furthermore, it is important to avoid temperature fluctuations, since recrystallization causes melting of ice crystals leading to surface dehydration and consequently freezer burns. Every time the temperature drops again, existing ice crystals increase their size, resulting in the loss of fish quality (Fellows, 2000).

During the time that the product is dipped in the glazing/ coating solution its temperature raises. A temperature profile is established from the surface to the centre of the product that depends on the solution/product temperature, product thickness and dipping time (besides, of course, the thermal properties of product and surrounding fluid, which cannot be controlled). Temperature is a critical variable for the safety of a food product and therefore we introduced the concept of safe dipping time (SDT). SDT can be defined as the maximum period of time that a frozen product may be dipped in a solution until which the (raising) product temperature does not constitute a hazard.

In order to correctly evaluate the SDT it will be necessary to know a) the particular conditions of glazing/coating application and $b$ ) the conditions to which the product will subsequently be subjected. Regarding a), during glazing operations in the frozen fish industry it is inevitable that the temperature of some parts of the product (certainly the surface and some volume below it) rise above $-5^{\circ} \mathrm{C}$, since glazing solutions are typically between 0.5 and $1.5^{\circ} \mathrm{C}$. This means that it is crucial to know how long it takes to have the whole product below $-5{ }^{\circ} \mathrm{C}$ again after glazing application, thus ensuring that pathogenic microorganisms will not have conditions to grow, i.e. it is crucial to consider also the conditions regarding b): the production room temperature, the time (after glazing) that the product takes to return to a freezing chamber and the freezing chamber temperature, which are the most important factors in that case. The conjugation of a) and b) will determine the safety threshold to be used when calculating the SDT, being such
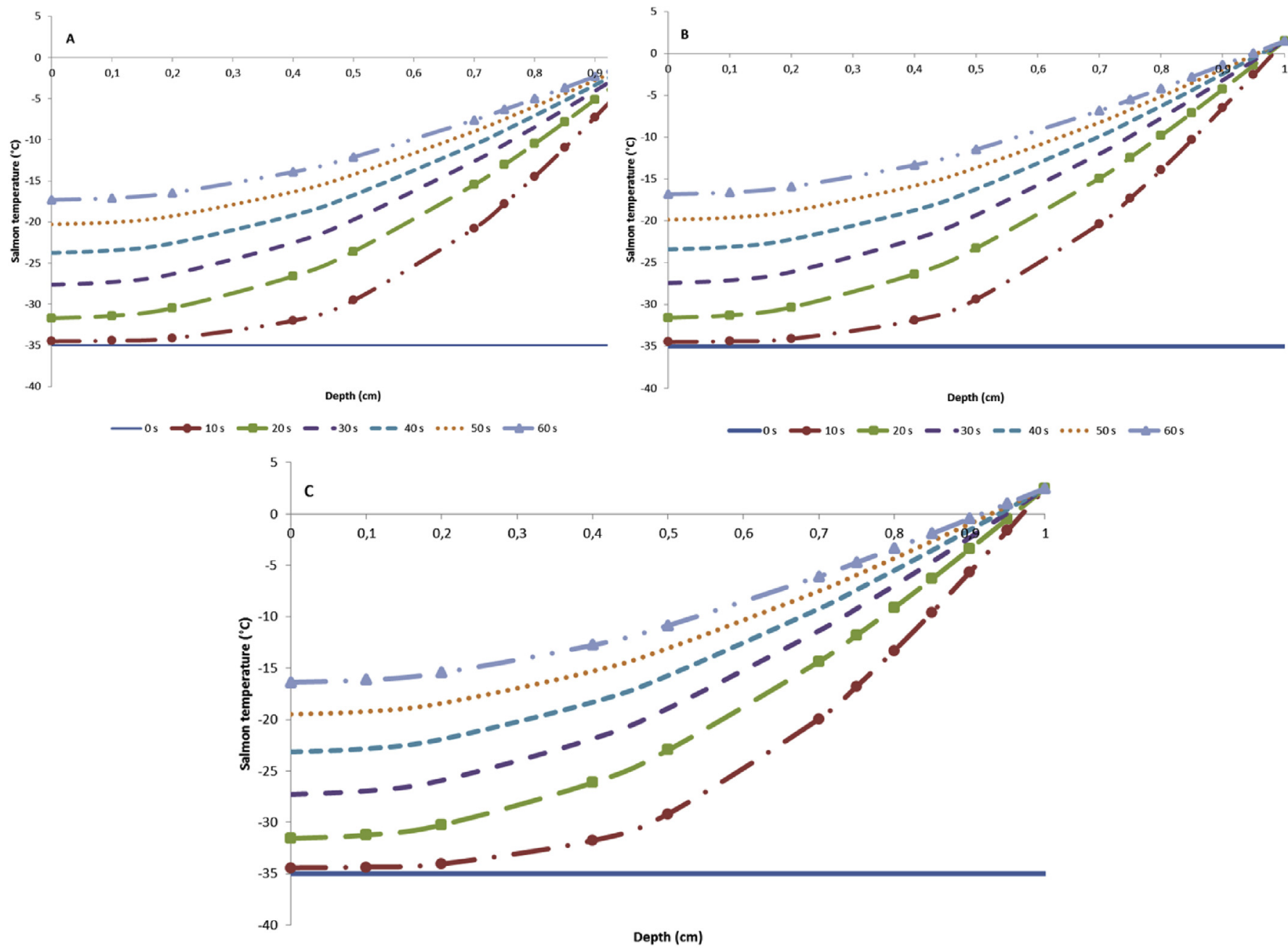

$\longrightarrow 0 s-10 s-20 s-30 s-60 s \ldots 50 s-60 s$

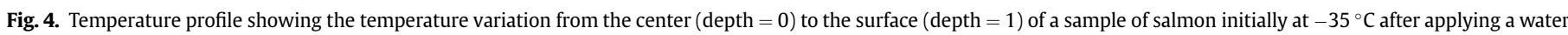
glazing at $0.5{ }^{\circ} \mathrm{C}(\mathrm{A}), 1.5^{\circ} \mathrm{C}(\mathrm{B})$ and $2.5^{\circ} \mathrm{C}(\mathrm{C})$. Each curve corresponds to a different dipping time. 
Table 2

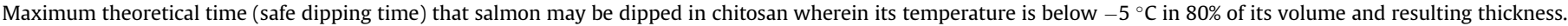

\begin{tabular}{|c|c|c|c|}
\hline Salmon temperature $\left({ }^{\circ} \mathrm{C}\right)$ & Chitosan temperature $\left({ }^{\circ} \mathrm{C}\right)$ & Safe dipping time (s) & Thickness (mm) \\
\hline \multirow[t]{3}{*}{-25} & 2.5 & 30 & $1.10 \pm 0.02$ \\
\hline & 5 & 20 & $0.57 \pm 0.03$ \\
\hline & 8 & 10 & $0.56 \pm 0.06$ \\
\hline \multirow[t]{3}{*}{-20} & 2.5 & 20 & $0.87 \pm 0.03$ \\
\hline & 5 & 10 & $0.69 \pm 0.04$ \\
\hline & 8 & 10 & $0.48 \pm 0.04$ \\
\hline \multirow[t]{3}{*}{-15} & 2.5 & 10 & $0.63 \pm 0.03$ \\
\hline & 5 & 5 & $0.55 \pm 0.02$ \\
\hline & 8 & 5 & $0.36 \pm 0.02$ \\
\hline
\end{tabular}

threshold defined in terms of the volume of the product that can be kept above $-5{ }^{\circ} \mathrm{C}$ during the whole process $\left.(a)+b\right)$ ). For the particular conditions of this work, it was defined that such threshold would correspond to ca. $20 \%$ of the total samples volume; this value is only an estimation based on the experience and particular conditions of Vanibru, Lda. and has been used just to allow demonstrating how does the SDT concept works. From Fig. 4 it is possible to check the salmon temperature in each one of its points after being immersed in water at various temperatures for various dipping times (Vanibru, Lda. conditions).

In order to simplify the analysis of the temperature profiles of the salmon samples, Tables 2 and 3 summarize the theoretical SDT for different salmon and coating temperatures. As expected, the maximum time that salmon may be dipped in both coatings increases with the decrease of salmon temperature and coating temperature. In general, as the temperatures used are lower in the water glazing than in chitosan coating, the safe dipping times are always higher in water.

The definition of safe dipping time for the various dipping conditions allowed the comparison of the maximum coating thickness where the salmon is still within the limits of food safety. Thus the glazing conditions to favor are those that present the longer dipping time and higher temperatures in order to reduce energy costs while continuing to be safe. When comparing the safe dipping time obtained for chitosan solution and water at the same coating/glazing temperature it can be concluded that in both cases this time is $30 \mathrm{~s}$, but the resulting thickness for chitosan coating is much higher reaching $1.10 \pm 0.02 \mathrm{~mm}$, while water glazing only reaches $0.61 \pm 0.03 \mathrm{~mm}$. The greatest thickness obtained for water glazing was $0.71 \pm 0.02 \mathrm{~mm}$ for a salmon temperature of $-25{ }^{\circ} \mathrm{C}$, water temperature of $0.5^{\circ} \mathrm{C}$ and dipping time of $40 \mathrm{~s}$. In comparison, the application of chitosan solution at $5{ }^{\circ} \mathrm{C}$ in salmon at $-20{ }^{\circ} \mathrm{C}$ for $10 \mathrm{~s}$ leads to a thickness of $0.69 \pm 0.04 \mathrm{~mm}$. The thickness values obtained in both cases are quite similar, however in the case of chitosan coating both chitosan solution and salmon are at higher temperatures, resulting in energy savings. As for dipping time, a reduction from 40 to $10 \mathrm{~s}$ leads to obvious savings in processing time.

\section{Conclusions and future perspectives}

From the analysis of the coating thicknesses resulting from the application of chitosan solutions on frozen salmon samples it can be concluded that the lower the salmon/chitosan solution temperature used, the higher the final coating thickness: when the chitosan coating temperature was lowered from $8{ }^{\circ} \mathrm{C}$ to $2.5^{\circ} \mathrm{C}$ there was an increase in coating thickness of $80 \%$ (for salmon temperature of $-25{ }^{\circ} \mathrm{C}$ and $20 \mathrm{~s}$ dipping time). It was also possible to conclude that the decrease in coating temperature had a more significant effect for the lower dipping times; in these cases the average increase in coating thickness for salmon at $-25^{\circ} \mathrm{C}$ (when the chitosan coating temperature was lowered from $8{ }^{\circ} \mathrm{C}$ to $2.5^{\circ} \mathrm{C}$ ) was $51 \%$ for a dipping time of $30 \mathrm{~s}$ and only $14 \%$ for dipping times between $40 \mathrm{~s}-60 \mathrm{~s}$. Lowering the salmon temperature by $10{ }^{\circ} \mathrm{C}$ resulted in an average increase of the coating thickness (considering all coating temperatures) of $40-43 \%$. Finally, it was observed that thickness always increased with dipping time, being $60 \mathrm{~s}$ not a limit to the thickness increase.

The evaluation of thickness resulting from the application of water glazing showed that, when compared with chitosan solution, water has less ability to freeze on salmon surface. The values of thickness obtained for salmon at $-25{ }^{\circ} \mathrm{C}$ and glazing/coating at $2.5^{\circ} \mathrm{C}$ shows that after $60 \mathrm{~s}$, the thickness of water glazing is smaller than chitosan coating at $10 \mathrm{~s}$.

The dipping time of $60 \mathrm{~s}$ is not a limiting factor for chitosan coated samples, although it was, in some cases, for the water-glazed samples. In the particular case of salmon at $-15{ }^{\circ} \mathrm{C}$ and water at $2.5^{\circ} \mathrm{C}$, the coating thickness even starts to decrease after $40 \mathrm{~s}$ dipping time.

This work introduces two new challenges for a frozen fish industry that aims to be more ethical and safe: one is the evaluation of glazing/coating by its thickness (and not by weight percentage, as it is presently done) aiming at defining objectively the amount of solution that is necessary to guarantee the protection of the product during shelf-life (independently of product shape or operational conditions); the other is the concept of Safe Dipping Time that is also related to the process of glazing/coating but until

Table 3

Maximum theoretical time (safe dipping time) that salmon may be dipped in water wherein its temperature is below $-5{ }^{\circ} \mathrm{C}$ in $80 \%$ of its volume and resulting thickness.

\begin{tabular}{|c|c|c|c|}
\hline Salmon temperature $\left({ }^{\circ} \mathrm{C}\right)$ & Water temperature $\left({ }^{\circ} \mathrm{C}\right)$ & Safe dipping time (s) & Thickness (mm) \\
\hline \multirow[t]{3}{*}{-25} & 0.5 & 40 & $0.71 \pm 0.02$ \\
\hline & 1.5 & 30 & $0.62 \pm 0.02$ \\
\hline & 2.5 & 30 & $0.61 \pm 0.03$ \\
\hline \multirow[t]{3}{*}{-20} & 0.5 & 30 & $0.58 \pm 0.02$ \\
\hline & 1.5 & 20 & $0.44 \pm 0.02$ \\
\hline & 2.5 & 20 & $0.42 \pm 0.04$ \\
\hline \multirow[t]{3}{*}{-15} & 0.5 & 20 & $0.42 \pm 0.02$ \\
\hline & 1.5 & 10 & $0.34 \pm 0.02$ \\
\hline & 2.5 & 10 & $0.24 \pm 0.01$ \\
\hline
\end{tabular}


now somehow is neglected by the industry, that is: how much the temperature of the solution raises the product temperature and if it will be enough to allow pathogenic microorganisms to grow. Further research should be done in these areas in the next years in order to implement the use of these concepts by the frozen fish industry, especially regarding the establishment of a model to determine the safety threshold to be used in the calculation of SDT.

\section{Acknowledgments}

The contribution of VANIBRU, Lda. regarding the PhD scholarship of Nuno Soares and the use of industrial facilities is gratefully acknowledged.

\section{References}

Baldwin, E.A., 2007. Surface Treatments and Edible Coatings in Food Preservation. Handb. Food Preserv, second ed., pp. 477-507. http://dx.doi.org/10.1201/ 9781420017373.ch21

Crank, J., 1979. The Mathematics of Diffusion. Clarendon Press.

De Azeredo, H.M.C., 2012. Edible coatings. In: Rodrigues, S., Fernandes, F.A.N. (Eds.), Advances in Fruit Processing Technologies. CRC Press, pp. 345-361.

Debeaufort, F., Quezada-Gallo, J.A., Voilley, A., 1998. Edible films and coatings: tomorrow's packagings: a review. Crit. Rev. Food Sci. Nutr. 38, 299-313. http:// dx.doi.org/10.1080/10408699891274219.

EFSA, 2011. Scientific Opinion on the Substantiation of Health Claims Related to Chitosan and Reduction in Body Weight (ID 679,1499), Maintenance of Normal Blood LDL-cholesterol Concentrations (ID 4663), Reduction of Intestinal Transit Time (ID 4664) and Reduction, vol. 9, pp. 1-21. http://dx.doi.org/10.2903/ j.efsa.2011.2214.

El-Hefian, E.A., Elgannoudi, E.S., Mainal, A., Yahaya, A.H., 2010. Characterization of chitosan in acetic acid: rheological and thermal studies. Turk. J. Chem. 34
47-56. http://dx.doi.org/10.3906/kim-0901-38.

FDA, 2011. Seafood - Fish and Fishery Products Hazards and Controls Guidance, fourth ed.

Fellows, P., 2000. Food Processing Technology. Woodhead Publishing Limited, Cambridge, England.

Ghaly, a E., Dave, D., Budge, S., Brooks, M.S., 2010. Fish spoilage mechanisms and preservation techniques: review department of process engineering and applied science, Dalhousie University Halifax, Nova Scotia, Canada. Am. J. Appl Sci. 7, 859-877. http://dx.doi.org/10.3844/ajassp.2010.859.877.

Huss, H.H., Ababouch, L., Gram, L., 2004. Assessment and Management of Seafood Safety and Quality. Food and Agriculture Organization of the United Nations (Rome).

James, D., 2013. Risks and Benefits of Seafood Consumption. Food and Agriculture Organization of the United Nations (Rome).

Jay, J.M., 2012. Modern Food Microbiology. Springer Science \& Business Media.

Johnston, W.A., Nicholson, F.J., Roger, A., Stroud, G.D., 1994. Freezing and Refrigerated Storage in Fisheries - FAO Fisheries Technical Paper - 340. FAO, Rome.

Rodriguez-Turienzo, L., Cobos, A., Moreno, V., Caride, A., Vieites, J.M., Diaz, O., 2011 Whey protein-based coatings on frozen Atlantic salmon (Salmo salar): influence of the plasticiser and the moment of coating on quality preservation. Food Chem. 128, 187-194. http://dx.doi.org/10.1016/j.foodchem.2011.03.026.

Soares, N.M.F., Oliveira, M.S.G., Vicente, A.A., 2015. Effects of glazing and chitosanbased coating application on frozen salmon preservation during six-month storage in industrial freezing chambers. LWT - Food Sci. Technol. 61, 524-531. http://dx.doi.org/10.1016/j.lwt.2014.12.009.

Srinivasa, P.C., Tharanathan, R.N., 2007. Chitin/Chitosan - safe, ecofriendly packaging materials with multiple potential uses. Food Rev. Int. 23, 53-72. http:// dx.doi.org/10.1080/87559120600998163.

Vanhaecke, L., Verbeke, W., De Brabander, H.F., 2010. Glazing of frozen fish analytical and economic challenges. Anal. Chim. Acta 672, 40-44. http:// dx.doi.org/10.1016/j.aca.2010.03.045.

Žoldoš, P., Popelka, P., Marcinčák, S., Nagy, J., Mesarčová, L., Pipová, M., Jevinová, P., Nagyová, A., Mal'a, P., 2011. The effect of glaze on the quality of frozen stored Alaska pollack (Theragra chalcogramma) fillets under stable and unstable conditions. Acta Vet. Brno 80, 299-304. http://dx.doi.org/10.2754/ avb201180030299. 